UDK 911.3

\title{
TOURIST ACTIVITY OF SELECTED STUDENTS OF THE KHMELNYTSKYI HUMANITARIAN-PEDAGOGICAL ACADEMY (UKRAINE)
}

\author{
Kamila Ziółkowska-Weiss (iD, Anastasiia Podliuk \\ Pedagogical University in Krakow, \\ Podchorażych St., 2, PL-30-084 Krakow, Poland, \\ e-mail:kamilazw@up.krakow.pl
}

This article is about tourist activity of the selected students of the Khmelnytskyi HumanitarianPedagogical Academy in Khmelnytskyi (Ukraine). The article discusses topics concerning tourist activity among young people. The empirical research presented in the article has been conducted among selected students of the Khmelnytskyi Humanitarian-Pedagogical Academy in Khmelnytskyi in Ukraine at the Department of the Preschool Pedagogy, specialization 014 "Teacher of English and foreign literature".

Tourism is a phenomenon of universal culture, a measure of self-fulfilment of a human being. Almost all of us undertake tourist activity. Increasingly, it is becoming an important and inalienable part of spending free time in contemporary society, influencing the quality, level and lifestyle of the society. The level of this activity depends on numerous factors, including socio-demographic, cultural and economic ones.

In the research, the author focused on getting to know the motives for travelling by students, their main purpose of travel, the amount of money they spend on travelling, a company they travel with, means of transport most frequently used for their journeys and whether they use the services of travel agencies while organizing trips. In the conducted research, a survey questionnaire has been applied as one of the marketing research methods.

As the conducted research has confirmed, the research group selected by the authors is very active taking into account tourism. The respondents are willing to travel several times a year, organize trips with designated goals (rest, adventure, willingness to learn about culture) and their main motivation for travelling is a desire to relax, experience the adventure and practice sports during the trip.

Key word: students, tourist activities, tourism, Ukraine, questionnaire.

Worldwide, tourism is a phenomenon that is changing and it constitutes the fastest growing activity in the world, which is confirmed, among other things, by UNWTO annual reports. The multi-dimensional nature of tourism can be considered in 5 aspects: cultural, economic, social, psychological and spatial. According to K. Przecławski [8, p. 35] tourism is: "The whole of phenomena of space movement connected with voluntary temporary change of place in space, change of the life rhythm and environment and getting into personal contact with the visited environment (natural, cultural or social)". The World Tourism Organization (WTO) at the International Conference in Ottawa in 1991 defined: "Tourism covers the general activities of people who travel and stay for leisure, business or other purposes, for no more than a year

(C) Ziółkowska-Weiss K., Podliuk A., 2019

ว Open Access

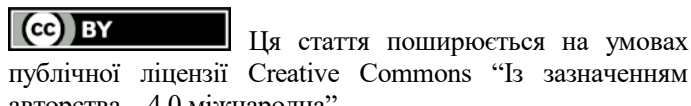
авторства - 4.0 міжнародна" 
without a break, outside of their daily life surroundings, excluding trips where the main purpose is gainful activity remunerated in the visited city".

One of the most respected tourism researchers from the industry point of view is a representative of the Danish scientific school N. Leiper. According to him, tourism is at the same time a kind of activity, a form of recreation as well as a branch of the national economy, a means of entertainment and art, science and business. The researcher developed a model of the tourism system that combines three main elements: tourists, geographical elements and tourist industry. Tourists as the entities of the system create a demand for tourist services and the need for functioning of the entire tourist system. Creation of the tourist infrastructure aims at the maximum satisfaction of the existing needs of tourists through an offer of transfer services, accommodation, meals, entertainment, etc. In turn, geographical elements are divided into regions visited by tourists, transit regions and tourist destinations [14, p. 144-159].

L. Hudman and R. Jackson [4] stated that tourism in all its concepts includes mutual elements: purpose, length of stay (it is determined, not permanent) and moving between several places. A tourist is a person who stays (travels) outside of the areas of permanent residence for 24 hours or more. According to W. Gaworecki, [2, p. 57] a person "traveling for pleasure, for family, health and other purposes; Going to meetings or as representatives on scientific, administrative, diplomatic, sports affairs, etc.; Traveling for commercial purposes; Participants in sea voyages, even if their duration of stay does not exceed 24 hours" can be considered to be a tourist.

The World Tourism Organization distinguishes the following groups of tourist motives, objectives of the visits in arrival, departure and domestic tourism for statistical research: "Rest, recreation, holidays - e.g. sightseeing, shopping, hiking, climbing, beach recreation, amateur sport, participation in sports and cultural events, honeymoon; visiting relatives and acquaintances - for instance, participation in celebrations, family gatherings, holiday trips to relatives and friends; professional matters, interests - e.g. trips to other companies, participation in conferences, congresses, fairs, study trips, language courses, scientific research, concert performances; professional goals - for instance, stay in health resorts and sanatoriums, therapeutic trips, slimming and health holidays; religious purposes e.g. participation in pilgrimages and various religious events; others - e.g. transit, travels of the crews of ships and passenger planes" [3, p. 79].

The above analyses confirm that tourist traffic cannot be limited only for recreational purposes. Travelling for business, scientific, sports, religious and social purposes also constitute tourism movement. In the Polish and world literature, definitions of "tourist traffic" can be found in almost each book related to tourism. Anna Nowakowska [7, p. 42] in her work entitled "Monographs" No. 88, described tourism as “... travels undertaken for pleasure, rest or treatment - on foot or by any means of communication. Therefore, their scope does not include travelling for gainful purposes or for the purpose of changing permanent residence (settling)".

G. Gołembski [3] describes tourism as a voluntary, temporal spatial movement outside the place of permanent residence for recreational, cognitive, medical and recreational purposes.

A well-known Ukrainian researcher in the field of tourism geography M. Kraczylo considered tourism to be a type of recreation, active relaxation, in which restoration of the capacity to work is combined with recreational, cognitive, sports and cultural and entertainment [13].

I. Zorin and V. Kvartalnov [12, p. 56] provide various definitions of the concept of tourism. They define it as "the type of travel; movement (moving) outside the place of permanent 
residence; a form of psychological and physical education, implemented through social and humanitarian functions; a popular form of organizing relaxation, leisure time; a branch of the economy that temporarily provides services to people outside their place of residence; a special form of movement of people on the route in order to visit particular facilities or to meet personal needs".

Tourism manifests itself as a form of public consumption of specific goods, services and products, which objectively evolved as a result of sociology of the reproductive function, creating a branch of activity for the creation of this specific product and organization of its consumption that due to its ultimate goal and nature belongs to the consumption sectors of the economy. Therefore, tourism can be defined as a set of phenomena and relationships that arise in the interaction of tourists, suppliers, local authorities and local people.

The main purpose of the research was to conduct a survey questionnaire among students about their tourism activity. This activity was examined among students of the Faculty of Preschool Pedagogy of the Khmelnytskyi Humanitarian-Pedagogical Academy in Khmelnytskyi, at the specialization 014 "An English and foreign literature teacher". The willingness of the students to familiarize with the closest surrounding cultural and geographic areas as well as with regions that are more distant and other countries was examined. In the conducted research, one of the marketing research methods, i.e. a survey questionnaire, was applied. The survey questionnaire is a written form of the respondents' answers to a set of questions asked by the interviewer. At the beginning of the questionnaire there is a general question regarding the age, gender, social characteristics, economic situation, demographic characteristics and place of residence of the respondents. These are the so-called demographics.

The survey questionnaire that was created in order to carry out this research included a question concerning the types, goals, reasons for departure, frequency and preferred length of trips. Respondents from the Khmelnytskyi Humanitarian-Pedagogical Academy in Khmelnytskyi were also asked about the means of transport, which they usually travel by during tourist trips.

Preparation of the questionnaire surveys consists in developing a questionnaire for survey research and selecting an appropriate number of populations for research, i.e. conducting the socalled selection of a representative sample. In the case of the described research, it was a group of students of the Faculty of Preschool Pedagogy, specialization "An English and foreign literature teacher" of the Khmelnytskyi Humanitarian-Pedagogical Academy in Khmelnytskyi in Ukraine.

The research regarding attractiveness and choice of the tourist destinations was conducted on 14 February 2019. The questionnaire survey was conducted in the Ukrainian and English language. 124 people took part in the research. The survey questionnaire used in this research consisted of 17 questions, including 5 general ones and 12 open and closed type research questions. In this study, apart from characteristics of the respondents, selected answers concerning tourist activity of the Ukrainian students will be presented. Their choice of the tourist destination is described in another article.

In the case of several questions, it was possible to provide multiple replies to the posed question. Each voluntary departure from the place of permanent residence during which the traveller has made at least one overnight stay outside the place of permanent residence was regarded as a trip (both domestic and foreign). This information and understanding the definition of "travelling outside the place of permanent residence" was given to the respondents 
before they proceeded to complete the questionnaire. The research did not include foreign trips whose purpose was undertake gainful employment in another country.

Description and characteristics of the University in Khmelnytskyi. The city of Khmelnytskyi, where the University is located, in which the research was conducted, is situated in the western part of Ukraine in the middle of the Volhynian-Podolian Upland (see figure).

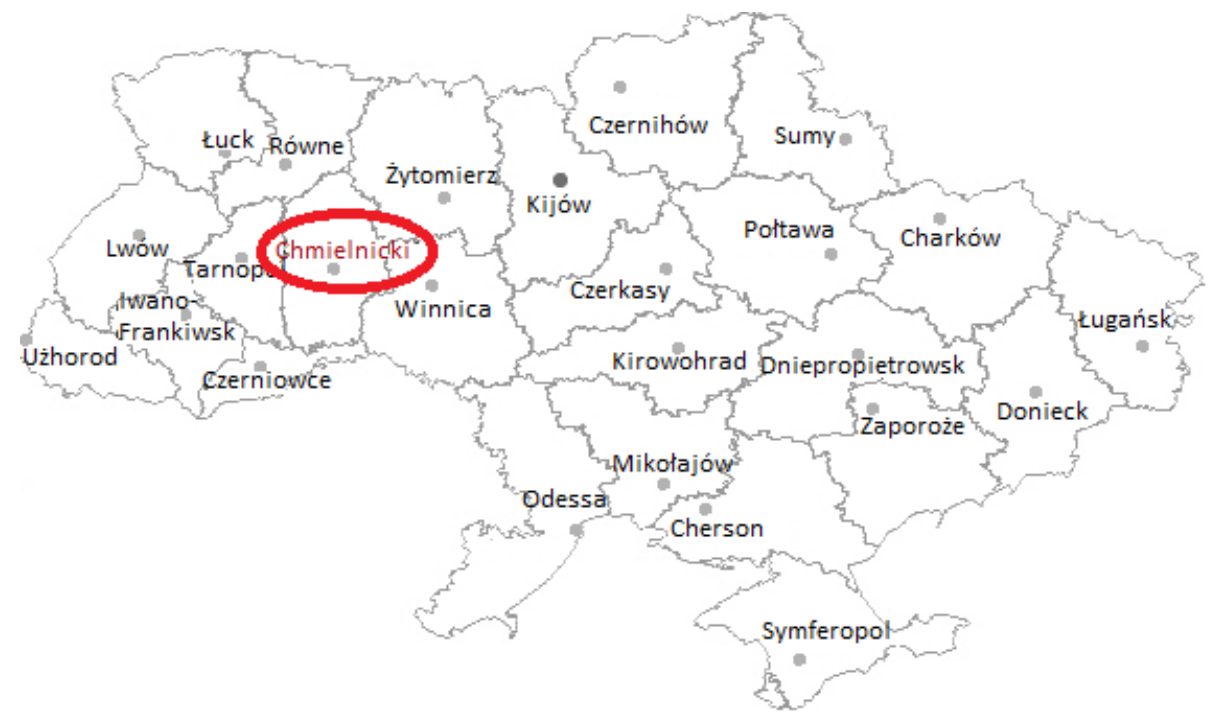

Khmelnytskyi City on the map of Ukraine

Місто Хмельницький на карті України Source: own study

Khmelnytskyi is dynamically developing and it is a modern symbol of the region. New residential areas are quickly emerging in the city and modern infrastructure is being built. New school and pre-school educational facilities are also established, sports fields and playgrounds are being built. Khmelnytskyi Humanitarian-Pedagogical Academy is located at 139 Proskurivskogo Pidpillia St., in the city centre.

Khmelnytskyi Pedagogical Academy is one of the oldest higher institutions in Podolia (historical and geographical area of Ukraine that occupies the basin of the Southern Bug and the left Dniester stream, including the territory of modern Vinnytsia, Khmelnytskyi, Ternopil and small areas of Ivano-Frankivsk and the Lviv regions). Since the opening of the Pedagogical Academy in the former city of Proskurov in 1921, the university has changed a lot. Starting with the basic pedagogical courses, later as a College, Institute, the Academy was and has been at the centre of the educational events in Ukraine. As of today, the university consists of three faculties: Faculty of Primary Education and Philology, Faculty of Pre-school Pedagogy, Faculty of Arts.

Khmelnytskyi Humanitarian-Pedagogical Academy in Khmelnytskyi offers dozens of specialties for students, including an English and foreign literature teacher at which the research has been carried out. The choice of students in this field was intentional, due to their knowledge of English, which in the case of the international research was an obvious choice, facilitating communication between students and persons conducting the research. The team carrying out 
the research included individuals from Poland and Ukraine and knowledge of English allowed for quick and efficient communication between researchers and respondents.

Characteristics of the respondents. Khmelnytskyi Humanitarian-Pedagogical Academy is one of the largest institutions providing educational services in this city. The number of students exceeds 2,500 people at this Academy. The presented article uses a quantitative research method in the form of a diagnostic survey that is a survey questionnaire. 124 people were selected for the research including 108 women and 16 men. The respondents were divided into four age groups. The questionnaire consisted of 17 questions including 5 general and 12 open and closed type research questions.

The subjects were divided into four age groups. In the first age group from 17 to 20 years of age, 93 people were examined, which constituted the most numerous research group among all other examined age groups and amounted to $75 \%$ of all respondents, respectively. The next group of the examined population was in the age rage 20-23 years of age was much smaller than the previous one and amounted to only 19 people $(15.3 \%)$. The next group included individuals aged 23-26. They constitute only $1.6 \%$ of the total number of respondents and as a result, it is the smallest research group. The fourth group included people of a different age than the above-mentioned ones. Their number was only 10 people $(8.1 \%)$.

A significant number of villages surrounds the city of Khmelnytskyi where the Khmelnytskyi Humanitarian-Pedagogical Academy is located. Thanks to this, a very large number of inhabitants of the rural areas have the opportunity to study, for example, at the Khmelnytskyi Humanitarian-Pedagogical Academy. Analysing the place of residence of the respondents it can be seen that 84 people $(67.7 \%)$ of the examined group live in the city, including 75 women and 9 men. In the rural areas, $32.3 \%$ of all examined students, i.e. 40 people, live.

The research also included the level of affluence of the families of the examined group of students. 101 people $(81.46 \%)$ assessed the level of income in their family as moderate, average. 13 people stated that the level of affluence in the family is high whereas the smallest research group included students who estimated their level of wealth to be very low. This answer was provided by $8.1 \%$ respondents, which constituted 10 people respectively.

While conducting the research the authors also wanted to check where students have money from for their tourist activity. Therefore, the questionnaire included a question about sources of income. In the conducted research, as many as $75 \%$, i.e. 93 people out of 124 respondents, were in the age group of 17-20. These are students who do not undertake employment yet and as the research has confirmed their main source of income is the money they receive from their parents. 40 people out of 124 work and, as a result, they have an additional source of income, which can be used even for travelling and tourism. 35 respondents receive a scholarship. Only 5 people $(4.03 \%)$ chose the answer "other" and their source of income comes from resources other than work, scholarship or money received from parents.

Tourist activity among selected students of the Khmelnytskyi Humanitarian-Pedagogical Academy in Khmelnytskyi. Tourist activity is increasingly becoming an important and nontransferable part of spending free time in the contemporary society, influencing the quality, level and lifestyle of the society. The level of this activity depends on numerous factors, including socio-demographic, cultural and economic ones. [3].

Z. Skórny [9, p. 79] lists 10 types of human activity: scientific, social, tourist, educational, cultural, military, production, self-service, entertainment and artistic ones. 
On the other hand, W. Alejziak [1, p. 34] stated that through the tourist activity whose basic manifestation is action, a human being achieves the goals he or she sets. While describing tourist activity, we must take into account a factor or a set of factors that have an impact on attractiveness, a particular place or a route.

J. Warszyńska [11, p. 142] defines tourist activity as a "set of factors influencing development of tourism in each tourist area, town or route; it is a complex of tourist values and advantages of the reception (communication accessibility and tourist equipment). Both tourist values and reception values are interrelated and conditioned. They have a significant influence on the development, size and duration of tourism" [6].

From all the terms, the definition of "tourist activity" presented by W. Alejziak [1, p. 24] will be the most suitable. He defines it as "all activities and actions of people associated with their participation in tourism".

The main objective of the research was to determine the tourist activity level of the students at the Khmelnytskyi Humanitarian-Pedagogical Academy in Khmelnytskyi. Several questions from the survey questionnaire were applied for this term. Answers and interpellation for particular questions are presented below. One of the questions concerned the desire to travel.

Travelling is one of the most pleasant ways to explore the world, relax and participate in recreational activities. 123 people from 124 answered "yes" to the question "Do you like travelling?" which constituted $99.2 \%$ of the examined group. Only one person (male) responded differently indicating that he did not like traveling.

The next asked question concerned frequency of travelling, with reference to both domestic and foreign trips. The respondents had 5 variants of answers to choose from.

Most frequently, respondents travel 2-3 times a year (mostly in the summer and winter). This was the answer provided by 44 women and 8 men. Only 8 people $(6.46 \%)$ from the whole research group do not travel at all. On the other hand, 36 women and 4 men chose the answer that they willingly travel only once a year. The answer about travelling 3-4 times a year that was marked by 13 people was in the next place. 11 people, i.e. $8.9 \%$ of the examined population, travel more than four times a year.

The author also asked about duration of trips. Respondents had the choice of one-day trips, multi-day trips, weekly trips and trips longer than a week. Among the options of answers there was also the one "I do not travel". Students who organize their stay for 2-5 days constitute the largest research group. 68 people, i.e. $54.84 \%$ of the examined group, provided this answer. The group of people leaving for a week included 19 people $(15.33 \%), 16$ women and 3 men. According to the research, the number of people who prefer one-day trips and trips for more than a week is the same, i.e. 15 people in each group, which constitutes $12.3 \%$ of the whole examined group of students. Only $5.65 \%$, i.e. 7 people, marked the answer that they did not travel at all.

To the question "How many people are going on a trip with you?", 50 people $(40.32 \%)$ replied that one or two people. 43 people, i.e. $34.7 \%$ of the examined group chose the answer of 3-4 people. The number of people leaving for domestic or foreign trips in the company of more than 4 people was 24 people. The smallest group of students is a group that prefers travelling alone. Only 7 people $(5.6 \%)$ responded this way.

The authors also asked who the respondents like travelling with most. The research confirms that students like travelling most with their family. 54 people, i.e. $43.5 \%$, provided this answer. A group that is smaller by one person - that is 53 people, $42.7 \%$ of the respondents, chooses foreign or domestic trips with colleagues. The answer "with the group" to this question is 
chosen by only 10 people out of 124.7 people $(5.64 \%)$ prefer travelling alone, which is the least frequent answer.

Students were asked if they engaged the services of a travel agency to organize the trip. To the question "Do you engage the services of a travel agency while organizing a trip?" the vast majority of students answered "No". This response was provided by as many as 103 people, which constituted $83.06 \%$ of all respondents. Only $1 / 4$ of the whole research group engages the services of travel agencies.

In the survey questionnaire, there were questions whose aim was to check seasonality of the trips among students. The largest time of the students' activity is in the summer period, which is why most people travel during the summer. As many as 100 people, i.e. $80.65 \%$ of the respondents, stated that their trips take place in the period of June-August. The next answers are very similar to each other. The number of people leaving in September-November is 8, including 6 women and 2 men. Only 7 people are willing to travel in the winter (DecemberFebruary). On the other hand, trips made in March-May are chosen by 9 people, i.e. $7.25 \%$ of the respondents.

An important issue in the research was to capture the purpose of travelling among a selected research group. There was one of the questions where students could mark three answers. Most frequently, students leave for recreational purposes. This answer was provided by 110 people $(88.71 \%), 55$ people marked the answer of adventure survival and 52 people opted for cultural purposes. Fewer people marked trips for health purposes -32 people or to visit places they saw after watching them on TV programs - 33 people. 24 people implement their trips for sentimental purposes, i.e. visiting their families or friends. For $15.32 \%$ of the entire research group, i.e. for 19 people, the main purpose of travelling is the desire to entertain, the so-called partying.

The authors also asked about the motives for travelling. In the opinion of students of the Khmelnytskyi Humanitarian-Pedagogical Academy in Khmelnytskyi, for $75.81 \%$ of them, the main motive for travelling is resting, relaxation. 73 people are willing to spend time actively and the main motive for their travelling is the desire for adventure. 60 women and 13 men made this choice. 59 people (50 women and 9 men) chose sport and entertainment. 42 people $(33.87 \%)$ of the respondents experience the need for travelling. Only 30 students leave in their free time for business purposes. 12 people are motivated by the desire to work/study, i.e. to deepen their knowledge. 8 people are motivated by religious motives (only women) and 6 people chose the answer "other", using other motives in their trips than the above-mentioned ones.

The most popular means of transport among Ukrainian students is a car. 56 students chose this answer. $38.71 \%$ of the respondents, i.e. 48 people travel by plane. The answer "other" was chosen by 11 people, which could mean that they travel, e.g. by hitchhiking. The smallest group of answers is "airplane". This mode of transport was chosen by only 9 people, probably due to high transport costs. None of the respondents provided the answer "ferry".

The conducted research has enabled to implement the goals set in the introduction, among others to examine various factors of tourist activity of students, their willingness to travel and motives for travelling. The performed analysis allows formulating the following statement: the majority of students like travelling and they spend time in an active way, going on domestic and foreign trips.

As regards the goals and motives for students' trips, these are usually motives related to relaxation, culture and the desire to experience the adventure. 
Tourism cannot exist without a man, despite the fact that important elements are natural values and potential tourist infrastructure. On the other hand, a human being plays a significant role in tourism since he or she decides where and when to go, who to travel with and through whose services.

This article may be useful for potential travel agencies, e.g. in the preparation of excursions taking into account tourist preferences.

\section{СПИСОК ВИКОРИСТАНОЇ ЛІТЕРАТУРИ}

1. Alejziak W. Determinanty i zróżnicowanie społeczne aktywności turystycznej. Kraków: Wydawnictwo AWF, 2009.

2. Gaworecki W. Turystyka. Polskie Wydawnictwo Ekonomiczne, 2000.

3. Golembski G. Kompendium wiedzy o turystyce. Wydanie nowe, Warszawa: Wydawnictwo Naukowe PWN, 2009.

4. Jackson R. H., Hudman L. E. World regional geography: issues for today. New York: John Wiley \& Sons, 1986.

5. Kiptenko V., Lyubitseva O., Malska M., Rutynskiy M., Zan'ko Y., Zinko J. Geography of tourism of Ukraine // The geography of tourism of Central and Eastern European countries: Second edition. 2017. P. 509-551. doi:10.1007/978-3-319-42205-3_13

6. Kruczek Z., Zmyślony P. Regiony turystyczne. Wydawnictwo Proksenia, 2010.

7. Nowakowska A. Społeczno-ekonomiczne uwarunkowania ruchu turystycznego w układach przestrzennych. Kraków: AE, 1989. 316 s. (Zeszyty Naukowe / Akademia Ekonomiczna w Krakowie Ser. Specjalna: Monografie, ISSN 0209-1674; nr 88).

8. Przecławski, K. Humanistic foundations of tourism. Warszawa, 1986.

9. Skórny Z. Mechanizmy regulacyjne ludzkiego działania. Warszawa: Wydawnictwo Naukowe PWN, 1989.

10. Stasiak A., Włodarczyk B. Produkt turystyczny miejsca // Turyzm. 2003. Vol. 13(1). P. 55-80.

11. Warszyńska J. Główne problemy badawcze geografii turyzmu // Turyzm. 1999. Vol. 9(1). P. 37-50.

12. Зорин И. В., Квартальнов В. А. Энциклопедия туризма. М.: Финансы и статистика, 2014. $368 \mathrm{c}$.

13. Крачило Н. П. Основы туризмоведения. К.: Вища школа, 1980. 117 с.

14. Кручек $О$. А. Екологічний туризм як важливий чинник сталого розвитку туристичної галузі (праксеологічний аспект) // Наукові записки КУТЕП. Серія Філософські науки. 2010. Вип. 7. С. 144-159.

\section{REFERENCES}

1. Alejziak, W. (2009). Determinanty i zróżnicowanie społeczne aktywności turystycznej. Wydawnictwo AWF, Kraków (in Polish).

2. Gaworecki, W. (2000). Turystyka. Polskie Wydawnictwo Ekonomiczne (in Polish).

3. Gołembski, G. (2009). Kompendium wiedzy o turystyce. Wydanie nowe, Wydawnictwo Naukowe PWN, Warszawa (in Polish).

4. Jackson, R. H., \& Hudman, L. E. (1986). World regional geography: issues for today. New York: John Wiley \& Sons. 
5. Kiptenko, V., Lyubitseva, O., Malska, M., Rutynskiy, M., Zan'ko, Y., \& Zinko, J. (2017). Geography of tourism of Ukraine. The geography of tourism of Central and Eastern European countries: Second edition (pp. 509-551). doi:10.1007/978-3-319-42205-3_13

6. Kruczek, Z., \& Zmyślony, P. (2010). Regiony turystyczne. Wydawnictwo Proksenia (in Polish).

7. Nowakowska, A. (1989). Społeczno-ekonomiczne uwarunkowania ruchu turystycznego w układach przestrzennych. Zeszyty Naukowe, ser. Monografie, 88, Akademia Ekonomiczna w Krakowie (in Polish).

8. Przecławski, K. (1986). Humanistic foundations of tourism. Warszawa (in Polish).

9. Skórny, Z. (1989). Mechanizmy regulacyjne ludzkiego działania. Wydawnictwo Naukowe PWN, Warszawa (in Polish).

10. Stasiak, A., \& Włodarczyk, B. (2003). Produkt turystyczny miejsca. Turyzm, 13(1), 55-80 (in Polish).

11. Warszyńska, J. (1999). Główne problemy badawcze geografii turyzmu. Turyzm, 9(1), 3750 (in Polish).

12. Zorin, I. V., \& Kvartal'nov, V. A. (2014). Jenciklopedija turizma. Moscow: Finansy i statistika, 368 s. (in Russian)

13. Kraczylo, N. P. (1980). Osnovy turizmovedenija. Kiev: Vyshcha shkola, 117 s. (in Russian).

14. Kruchek, O. A. (2010). Ekolohichnyi turyzm yak vazhlyvyi chynnyk staloho rozvytku turystychnoi haluzi (prakseolohichnyi aspekt). Naukovi zapysky KUTEP. Seriia Filosofski nauky, 7, 144-159 (in Ukrainian).

Стаття: надійшла до редакиії 24.07.2019

доопраиьована 16.08.2019

прийнята до друку 05.09.2019

\section{ТУРИСТИЧНА ДІЯЛЬНІСТЬ ВИБРАНИХ СТУДЕНТІВ ХМЕЛЬНИЦЬКОЇ ГУМАНІТАРНО-ПЕДАГОГІЧНОЇ АКАДЕМІЇ (УКРАЇНА)}

\section{Каміла Зіолковська-Вайс, Анастасія Подлюк}

Краківський педагогічний університет, вул. Підхорунжих, 2, 30-084 Краків, Польща, e-mail:kamilazw@up.krakow.pl

Проаналізовано туристичну діяльність певної групи студентів Хмельницької гуманітарно-педагогічної академії (Україна). Розглянуто теми, пов'язані з туристичною діяльністю молоді. Емпіричні дослідження, представлені у статті, проводилися серед певної групи студентів Хмельницької гуманітарно-педагогічної академії м. Хмельницький в Україні на факультеті початкової освіти та педагогіки, за спеціальністю 014 “Вчитель англійської та зарубіжної літератури”.

Туризм - явище універсальної культури, засіб самореалізації людини. Майже кожен $з$ нас займається туристичною діяльністю. Все частіше туризм стає важливою та невід'ємною частиною розвитку вільного часу в сучасному суспільстві, впливаючи на якість, рівень та спосіб життя суспільства. Рівень цієї діяльності залежить від багатьох факторів, включаючи соціально-демографічний, культурний та економічний.

У ході дослідження зосереджено увагу на ознайомленні 3 мотивами подорожей студентів, їхньою основною метою, кількістю коштів, які вони витрачають, з ким вони подорожують, якими 
транспортними засобами вони найчастіше та чи користуюся подорожуючи, хто допоміг чи організував їхню мандрівку. У проведеному дослідженні використано один із методів маркетингових досліджень - анкетування.

Як показали дослідження, експериментальна група, вибрана авторами, дуже активно займається туризмом. Респонденти готові подорожувати кілька разів на рік, організовувати поїздки із визначеними цілями (відпочинок, пригоди, інтерес дізнатись більше про нову культуру), а їхня основна мотивація подорожей - бажання пережити пригоду та заняття спортом під час поїздки.

Ключові слова: студенти, туристична діяльність, туризм, Україна, анкетування. 